\title{
DEPOSITION OF AIRBORNE ORGANIC POLLUTANTS ON HISTORIC BUILDINGS
}

\author{
C. SAIZ-Jimenez \\ Instituto de Recursos Naturales y Agrobiologia de Sevilla, Apartado 1052, 41080 Sevilla, Spain
}

(First received 7 May 1992 and in final form 5 August 1992)

\begin{abstract}
The black crusts coating the surfaces of building materials located in urban (polluted) environments contain all kinds of organic compounds present in aerosols and particulate matter. Wet and dry deposition processes combined with gypsum crystal growth result in dirty, grey-to-black crust formation, in which aerosols, spores, pollen, dust and every class of particulate matter are entrapped in the mineral matrix. Analysis of the organic compounds extracted from black crusts demonstrate them to be mainly composed of molecular markers that are characteristic of petroleum derivatives. The composition of each crust is governed by the composition of the particular airborne pollutants in the area.
\end{abstract}

Key word index: Black crust, gypsum, petroleum biomarkers, fungi, pyrolysis.

\section{INTRODUCTION}

The Northern Hemisphere is experiencing a series of severe ecological problems with forest decline, acidification of lakes, and accelerated corrosion of monuments, buildings and metallic structures.

Thousands of chemicals are emitted directly or indirectly to the atmosphere because of human activities. These pollutants are distributed in the environment and the atmosphere is recognized as a major route for worldwide dispersion.

The interaction of materials with the atmosphere has recently received increased attention as a result of concerns regarding the effects of acid deposition. In fact, most pollutants emitted into the atmosphere are eventually removed through naturally occurring cleansing mechanisms. These removal and deposition processes represent the final stages of a complex sequence of atmospheric phenomena. Once released into the atmosphere, organic and inorganic airborne pollutants may undergo a variety of complex interactions determined by physical, chemical and photochemical processes occurring during their residence time. These processes influence the nature of the capture of the pollutants in a sink or reservoir, where they are transformed, immobilized or encapsulated (Schroeder and Lane, 1988).

The two mechanisms for transferring pollutants to material surfaces are defined as dry and wet deposition. Dry deposition proceeds without the aid of precipitation and denotes the direct transfer of gases and particulates to the Earth's surface. Wet deposition, on the other hand, encompasses all processes by which airborne pollutants are transferred to the Earth's surface in an aqueous form (i.e. rain, snow or fog). In this case, pollutants can become incorporated by two different mechanisms, in-cloud scavenging (rain-out), which is the main route for wet deposition and occurs when pollutants are included in the droplets developing within a cloud, and below-cloud scavenging (wash-out), which involves the take-up of pollution by precipitation as it falls from the cloud. This is a much less efficient removal process than in-cloud scavenging (Department of Environment, 1989).

Sulphur dioxide has long been recognized as the primary gaseous component of air pollution and a correlation exists between sulphur dioxide concentration and sulphatation of carbonatic stones, because oxidation of sulphur dioxide results in sulphuric acid production. In this process, carbonaceous particles are capable of greatly accelerating the destructive action, and behave as catalysts - they contain $\mathrm{V}, \mathrm{Ti}, \mathrm{Fe}, \mathrm{Mn}$, $\mathrm{Cu}-$ for the oxidation of sulphur dioxide. Aerosols in the form of sulphuric acid droplets also attack building limestone, the reaction ultimately resulting in gypsum formation.

Buildings and outdoor-exposed statues and monuments act as repositories of airborne organic pollutants, which accumulate at the surfaces in zones frequently soaked by rain water but are not washed out. Wet and dry deposition processes combined with gypsum crystal growth result in dirty, grey-to-black crust formation, in which aerosols, spores, pol'-in, dust and every class of particulate matter are entrapped in the mineral matrix.

The industrialized society of the 20th century has thus caused a radical change in the conditions of preservation and conservation of stone, and the atmospheric pollution associated with industrialization is currently threatening extinction for both cultural heritage and nature itself.

\section{COMPOSITION OF BLACK SULPHATED CRUSTS}

Generally, black and white areas can be observed on the exposed surfaces of any building. The black 
areas, found in zones protected from direct rainfall and from surface runs, are covered by an irregular, dendrite-like, hard crust composed of crystals of gypsum mixed with dust, aerosols and particulates of atmospheric origin. Among these the most abundant are black carbonaceous particles, originating from oil and coal combustion (vehicular emissions, power plants, domestic heating systems, etc.).

On the other hand, surfaces directly exposed to rainfall show a white colour, since the deterioration products formed on the stone surface are continuously washed out.

Gillberg et al. (1977) analysed soot and grime of buildings in Stockholm, which showed large amounts of inorganic materials (mainly sulphates), $2 \%$ of free carbon and $2 \%$ of organic compounds, represented by aliphatic hydrocarbons. Hoke (1978) reported that crusts from weathered stones sampled in Salzburg monuments reached $80 \%$ in gypsum concentration, and soot and organic compounds were also often found.

In Gauri (1978), the dirt on the surface of building stones was found to be primarily street soot that coats the stone and even embeds itself in the outer layers. Calcite, after it has been dissolved, may recrystallize on the same façade or may be transformed into gypsum. Many of the dirty encrustations on stone are in fact combinations of calcite and gypsum that in the process of chemical transformation have incorporated silica, fly ash and carbonaceous material from polluted air.

Del Monte et al. (1981) identified two types of particles in black crusts:

(i) spherical shaped, irregular rough surface and high porosity (assigned to oil-fired combustion plants);

(ii) spherical shaped, with smooth surface (derived from coal-fired combustion plants).

Both types of particles have diameters of about $10 \mu \mathrm{m}$ and contain carbon, silicon, sulphur, aluminium and calcium as major constituents.

Saiz-Jimenez and Bernier (1981) studied the gypsum crusts of some Sevillian monuments. Crusts were dissolved in $10 \mathrm{~N} \mathrm{HCl}$ and the insoluble material was washed several times with distilled water, centrifuged and dried. This material was found to be composed of quartz and aluminosilicates together with airborne carbonaceous particles of spherical shape, rough surface, high porosity and irregular pore distribution. The association gypsum crystals-black particles was very frequent in the samples. This association is so intimate that the matter making up the crust is, in fact, a compact agglomeration of gypsum and carbonaceous particles. These black carbonaceous particles appeared to behave not only as carriers of chemicals but also as gypsum-nucleating agents (Del Monte $e t$ al., 1984).

Although there is a consensus on the composition of black sulphated crusts in terms of gypsum and car- bonaceous particles, investigations into the chemical nature of the (individual) organic compounds entrapped in the crusts have seldom been undertaken.

\section{EXPERIMENTAL}

Knowledge of the organic chemistry of the weathered stones is important both for a description of the species and for understanding weathering and deposition processes. The analytical approach for studying the organic compounds present in black crusts should be feasible at microscale level and should supply fairly general information on a wide range of classes of compounds. With this aim two approaches were adopted. One was solvent extraction, in which relatively large amounts of material were analysed by standard techniques involving gas chromatography $(\mathrm{GC})$ in combination with mass spectrometry (MS). The other approach was analytical pyrolysis, a flash thermal desorption and degradation, also in combination with GC/MS, which allows the obtaining of fairly general composition data from microgram quantities of samples. Both methods were applied to a variety of samples obtained from cathedrals, churches, historic buildings and sculptures in Belgium, Ireland, Italy, Spain and the Netherlands.

For solvent extraction, $20 \mathrm{~g}$ of black crust were ground in an agate mortar and extracted in a Soxhlet apparatus. Two extracts were obtained by successive extractions with $200 \mathrm{ml}$ of toluene $(8 \mathrm{~h})$ and with $200 \mathrm{ml}$ of methanol $(8 \mathrm{~h})$. The use of methanol as solvent is reflected in the appearance of both organic and inorganic materials in the extract. The inorganic materials were eliminated by extraction with bidistilled cold water (three times). Both extracts were mixed and evaporated under vaccuum at low temperature (below $40^{\circ} \mathrm{C}$ ) and redissolved in diethylether. Acidic compounds were derivatized by addition of an excess of diazomethane solution in ether and, consequently, carboxylic groups were converted into methyl esters.

Extracts were injected in a GC/MS system. Methods and analytical conditions have been thoroughly described elsewhere (Saiz-Jimenez et al., 1991). Briefly, separation and identification of compounds was achieved using a fused-silica capillary column $(25 \mathrm{~m} \times 0.32 \mathrm{~mm}$ i.d.) coated with CP Sil 5 . The temperature programme was from $0^{\circ} \mathrm{C}(1 \mathrm{~min})$ to $320^{\circ} \mathrm{C}$ $(15 \mathrm{~min})$ at a rate of $3^{\circ} \mathrm{C} \mathrm{min}{ }^{-1}$. The analysis was performed with a HP $5890 \mathrm{GC}$ interfaced with a VG70-250 SE double focussing mass spectrometer operating under the following conditions: ionization energy $70 \mathrm{eV}$, mass range $m / z 50-800$, cycle time $2 \mathrm{~s}$. Alternatively, the extracts were deposited onto a Curie-point ferromagnetic wire $\left(358^{\circ} \mathrm{C}\right)$, the solvent evaporated, and the wire inserted in a pyrolysis unit mounted in the injection block of the same GC/MS system described above, under identical programming. This allows the compounds to evaporate by heating at $358^{\circ} \mathrm{C}$ for $10 \mathrm{~s}$, which avoids the solvent interferences.

Analytical pyrolysis was accomplished in the same instrument described above. In this case only a few micrograms of sample was needed for analysis. The sample was applied to a wire according to the method described by Venema and Veurink (1985) and pyrolysed for $10 \mathrm{~s}$ using an $\mathrm{Fe}$ wire with a Curie temperature of $770^{\circ} \mathrm{C}$. This temperature has been shown to be adequate for evaporation/pyrolysis of organic materials within mineral matrices (Saiz-Jimenez et al., 1991). However, some changes in the thermal breakdown of molecules could be expected, as the crust contains high percentages of gypsum and other salts and it has been demonstrated that cations influence the thermal behaviour of organic materials (van der Kaaden et al., 1983). Furthermore, some decarboxylation of organic acids was observed (SaizJimenez, 1991). 


\section{RESULTS AND DISCUSSION}

Identification of organic compounds in black crusts

As a general characteristic, the black crusts from monuments sampled in different locations and countries present a diversity of organic compounds entrapped in the mineral matrices. This diversity is determined by the different nature of the aerosols and particulates present in the atmosphere of each location. However, black crusts obtained from different building materials in the same spot had similar composition. This was observed, for example, in the Pardon Gate of the cathedral of Seville, which is the main entrance to the Orangery Court, remains of the Moorish mosque begun in 1172 . This arch is ornamented with arabesques of plaster, all inserted in a limestone wall, which constitutes the north front. Four terracotta statues representing Saint Peter, Saint Paul and the Annunciation, and a high relief representing the
Expulsion from the Temple were added in the 16th century. The four statues are sustained by an alabaster pedestal. Therefore, four types of building materials exist in the Pardon Gate:limestone, plaster, alabaster and terracotta.

Crusts from all these materials at a height of about $10 \mathrm{~m}$ from the ground, were sampled and analysed by analytical pyrolysis. This analytical approach was justified by the scarce amount of sample available. Figure 1A represents the total ion current (TIC) trace obtained from the black crust formed on terracotta. This was identical to those of crusts removed from alabaster, limestone or plaster, thus confirming that identical compounds are present in crusts of different materials exposed to the same polluted environment.

The TIC trace is dominated by homologous series of aliphatic hydrocarbons and a few polycyclic aromatic hydrocarbons. The aliphatic hydrocarbons most probably have a double origin, as they may arise
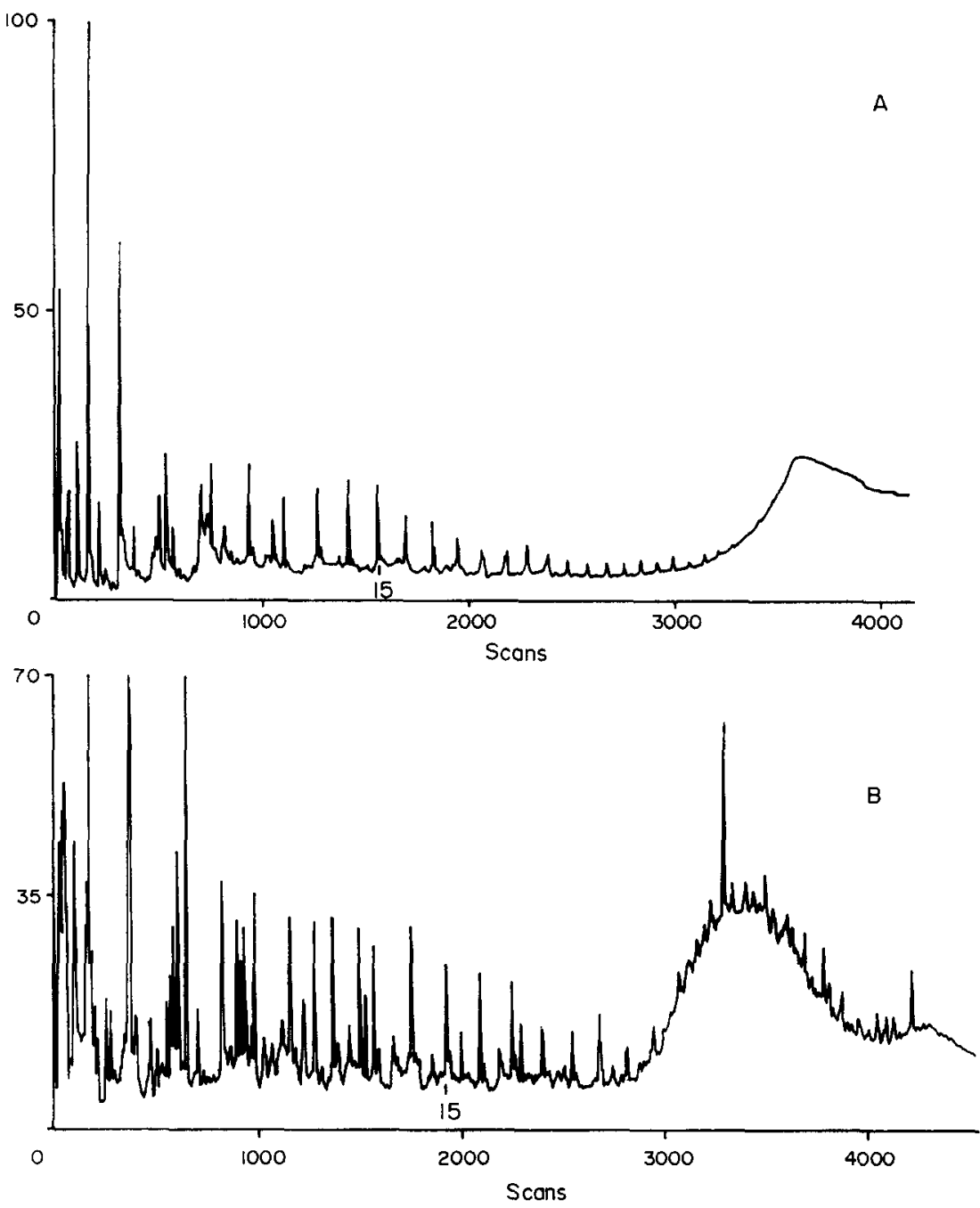

Fig. 1. (A) TIC trace of the pyrolysate obtained from a black crust on terracotta, Pardon Gate, cathedral of Seville. (B) TIC trace of the pyrolysate obtained from a black crust removed from the Prince Gate, cathedral of Seville. Number 15 refers to atom carbons of the alkane/alkene series. 
either from uncombusted or partially combusted fuels ( $n$-alkanes) or from pyrolytic decarboxylation of fatty acids (n-alk-1-enes). The polycyclic aromatic hydrocarbons, less abundant than the aliphatic hydrocarbons, were characterized by the presence of indene, naphthalene, fluorene, phenanthrene and pyrene. These compounds have an environmental significance because although present in oil, they also represent the product of incomplete combustion of gasoline and diesel fuel in vehicles (Boyer and Laitinen, 1975).

As observed by SEM and EDX, the black crusts present in the building materials from the Pardon Gate are composed of gypsum crystals originated by the reaction of sulphuric acid with the exposed materials. During the process, aerosols and particulates present in the polluted urban atmosphere are entrapped. The carbonaceous particles contain as mineral elements $\mathrm{S}, \mathrm{Al}, \mathrm{Ca}, \mathrm{Fe}, \mathrm{Cu}, \mathrm{Mn}$, and $\mathrm{V}$, and aliphatic hydrocarbons and polycyclic aromatic hydrocarbons as main organic compounds. Carbonaceous particles are very sorptive, have high levels of organic matter, and exhibit high specific surface areas. Polycyclic aromatic hydrocarbons were strongly sorbed by and difficult to extract from particles because their matrices contain silica, alumina, metal oxides and possibly even activated carbon, all of which are excellent adsorbents for organic compounds (Christwell et al., 1988).

In the south front, some $130 \mathrm{~m}$ distant from the north front, there is the Prince Gate, constructed in 1887. The entrance to this gate is protected by a fence supported by a small limestone wall and pilasters, which are severely deteriorated due to black crust formation. This is related to the fact that one of the main Sevillian bus terminals, operating for more than 20 years, was just in front and less than $10 \mathrm{~m}$ away from this wall. Exhaust gases and particulate matter heavily affected the limestone.

Interestingly, the TIC for this crust (taken only $1.7 \mathrm{~m}$ from the ground) was different to those removed from the north side, especially at the end of the analysis programme, characterized by a complex mixture of branched and cyclic hydrocarbons (hump or unresolved complex mixture) which can be seen in the range $\mathrm{C}_{20}-\mathrm{C}_{34}$ (Fig. 1B). The huge hump indicates a severe contamination by fossil fuels. The source of these hydrocarbons is confirmed by the suite of biomarkers. In fact, as crude oils usually contain tricyclic terpanes and hopanes, triterpanes have been proposed as sensitive molecular markers of petroleum pollution. The triterpanes of the black crust are composed of predominantly the $17 \alpha(\mathrm{H}), 21 \beta(\mathrm{H})$-hopane series, which is of petroleum origin. Tricyclic terpanes make them further possible indicators of petroleum. In addition, series of steranes were also present. Table 1 lists some of the identified compounds from the $\mathrm{m} / \mathrm{z}$ 191 mass chromatogram (Fig. 2) whereas in the crust removed from alabaster only $17 \alpha(\mathrm{H}), 21 \beta(\mathrm{H})-30-$ norhopane was clearly identified. These compounds are found in vehicular emissions, diesel fuel and lubri-
Table 1. Triterpanes and steranes identified in pyrolysates of black crusts (cathedral of Seville)

\begin{tabular}{|c|c|}
\hline Peak & Compound \\
\hline 1 & $\mathrm{C}_{23}$ tricyclic terpane \\
\hline 2 & $\mathrm{C}_{24}$ tricyclic terpane \\
\hline 3 & $\mathrm{C}_{25}$ tricyclic terpane \\
\hline 4 & $\mathrm{C}_{25}$ tetracyclic terpane \\
\hline 5 & $\mathrm{C}_{26}$ tricyclic terpane \\
\hline 6 & $\mathrm{C}_{27}$ tricyclic terpane \\
\hline 7 & $\mathrm{C}_{28}$ tricyclic terpane \\
\hline 8 & $\mathrm{C}_{29}$ tricyclic terpane $+5 \alpha, 14 \beta$-cholestane \\
\hline 9 & $17 \alpha(\mathbf{H})-22,29,30$-trisnorhopane \\
\hline 10 & 24-methyl-5 $\alpha, 14 \beta, 17 \beta(\mathrm{H})$-cholestane \\
\hline 11 & 24-ethyl-5 $5,14 \beta, 17 \beta(H)$-cholestane \\
\hline 12 & $17 \alpha(\mathrm{H}), 21 \beta(\mathrm{H})$-30-norhopane \\
\hline 13 & $17 \alpha(\mathbf{H}), 21 \beta(\mathbf{H})$-hopane \\
\hline 14 & $17 \alpha(\mathbf{H}), 21 \beta(\mathrm{H})$-homohopane $22 \mathrm{~S}$ \\
\hline 15 & $17 \alpha(\mathrm{H}), 21 \beta(\mathrm{H})$-homohopane $22 \mathrm{R}$ \\
\hline 16 & $17 \alpha(\mathrm{H}), 21 \beta(\mathrm{H})$-bishomohopane $22 \mathrm{~S}$ \\
\hline 17 & $17 \alpha(\mathrm{H}), 21 \beta(\mathrm{H})$-bishomohopane $22 \mathrm{R}$ \\
\hline 18 & $17 \alpha(\mathrm{H}), 21 \beta(\mathrm{H})$-trishomohopane $22 \mathrm{~S}$ \\
\hline 19 & $17 \alpha(\mathrm{H}), 21 \beta(\mathrm{H})$-trishomohopane $22 \mathrm{R}$ \\
\hline 20 & $17 \alpha(\mathbf{H}), 21 \beta(\mathbf{H})$-tetraquishomohopane $22 \mathrm{~S}$ \\
\hline 21 & $17 \alpha(\mathrm{H}), 21 \beta(\mathrm{H})$-tetraquishomohopane $22 \mathrm{R}$ \\
\hline 22 & $17 \alpha(\mathrm{H}), 21 \beta(\mathrm{H})$-pentaquishomohopane $22 \mathrm{~S}$ \\
\hline 23 & $17 \alpha(\mathrm{H}), 21 \beta(\mathrm{H})$-pentaquishomohopane $22 \mathrm{R}$ \\
\hline
\end{tabular}

cating oil and can be present in aerosols (Simoneit, 1985), therefore the origin of those encountered in the black crust can be directly ascribed to the vehicular exhausts originated by idling engines in the bus stop.

It is interesting to note that even in the same city and building, different orientations and environmental conditions originate distinct crust composition, as denoted by the influence of the bus stops in the Prince Gate crusts. In turn, the analytical approach used shows its sensitivity to differentiate organic compositions within samples.

To prove that different environments generate crusts with distinct composition, the organic compounds present in the crusts collected from monuments located in three cities, Dublin (Ireland), Mechelen (Belgium) and Seville (Spain) were investigated.

One sample corresponds to black sulphated crusts from the Custom House, an 18th century building in Dublin, constructed in 1791 with Portland limestone. In addition to damage to the fabric caused by the aggresive atmosphere of Dublin, and the damage caused by the corrosion of ferrous metals, the Custom House has suffered greatly from the effects of three major fires.

Crusts were collected from the balustrade removed from the east front during the restoration works accomplished in 1988. The crusts were situated on the back part of the railing, in a sheltered and rainprotected site. The railing and small columns were eroded and free from the black crust, except on the underside of the railing.

The Irish black crusts was compared with those collected from the Prince Gate in Seville (previously described), and the cathedral of Mechelen (1315 th century), whose building materials and architec- 


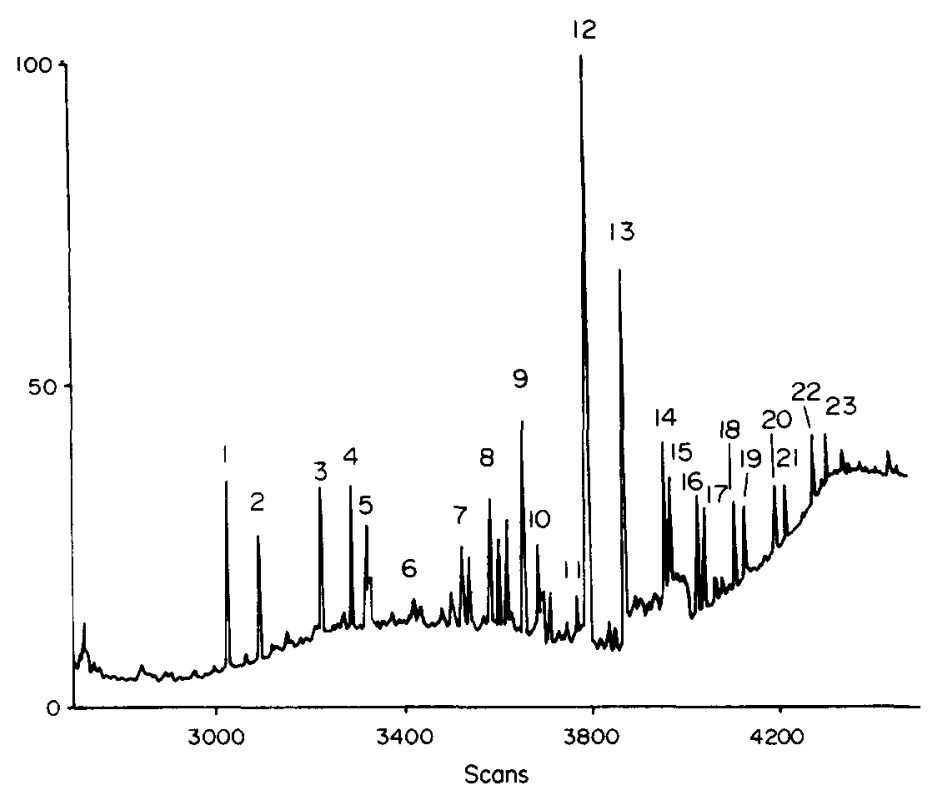

Fig. 2. Mass fragmentogram $(m / z 191)$ showing the distribution of triterpanes in the pyrolysate of a black crust, Prince Gate, cathedral of Seville.

Table 2. Some series of organic compounds present in black crusts

\begin{tabular}{llllllll}
\hline Location & $n$-Alkanes & $\mathrm{C}_{\max }$ & $\mathrm{CPI}$ & Fatty acids & $\mathrm{C}_{\max }$ & $\mathrm{CPI}$ & Triterpanes \\
\hline Dublin & $\mathrm{C}_{13}-\mathrm{C}_{35}$ & $\mathrm{C}_{29}$ & 1.3 & $\mathrm{C}_{10}-\mathrm{C}_{32}$ & $\mathrm{C}_{16}$ & 2.9 & $\mathrm{C}_{27}-\mathrm{C}_{34}$ \\
Mechelen & $\mathrm{C}_{14}-\mathrm{C}_{40}$ & $\mathrm{C}_{29}$ & 1.7 & $\mathrm{C}_{12}-\mathrm{C}_{34}$ & $\mathrm{C}_{16}$ & 5.1 & $\mathrm{C}_{27}-\mathrm{C}_{34}$ \\
Seville & $\mathrm{C}_{15}-\mathrm{C}_{40}$ & $\mathrm{C}_{31}$ & 1.0 & $\mathrm{C}_{10}-\mathrm{C}_{34}$ & $\mathrm{C}_{22}$ & 1.9 & $\mathrm{C}_{27}-\mathrm{C}_{35}$ \\
\hline
\end{tabular}

ture were characteristic of many large historic buildings throughout Flanders. Mechelen is situated on a straight line between Antwerp and Brussels, and the heavily industrialized areas north of Brussels, and especially north of Antwerp, are some 15 and $25 \mathrm{~km}$ away, respectively. Therefore, Mechelen lies at the centre of one of the world's most polluted areas and downtown traffic passes around most of the cathedral. Limestone from Balegem and Gobertingem was used for the original construction (Leysen et al., 1987).

In this case the studies were accomplished by extracting the samples with organic solvents, instead of by pyrolysis.

The extractable lipid material of the three samples consisted primarily of aliphatic hydrocarbons and fatty acids (as methyl esters), represented by homologous series of $n$-alkanes ranging from $\mathrm{C}_{13}$ to $\mathrm{C}_{40}$, and $n$-fatty acids from $\mathrm{C}_{10}$ to $\mathrm{C}_{34}$ (Table 2). Furthermore, diterpenoids, triterpanes, steranes, polycyclic aromatic hydrocarbons and dialkyl phthalates were identified.

For investigating sources of homologous series of compounds, the carbon preference index (CPI), which is the sum of the odd-carbon-number homologs over a specified range divided by the sum of the even-carbonnumber homologs over the same range, was utilized.
CPI of normal hydrocarbons for each sample was different. A more sensitive method requires splitting the carbon range into low $\left(\mathrm{C}_{15}-\mathrm{C}_{24}\right)$ and high $\left(\mathrm{C}_{25}-\mathrm{C}_{34}\right)$ ends. In this case, $\mathrm{CPI}$ for the Irish extract were 0.8 and 1.9, for the Belgian extract 1.1 and 2.1, and for the Spanish extract 0.8 and 1.1 , respectively. The lower end is representative of a petrogenic origin, as the typical CPI of petroleum is 1.0 , and petroleum residues are a major and usually predominant component of the lipids extractable from aerosols in urban environments (Simoneit, 1986). The high end, in the case of the Irish and Belgian extracts, demonstrated a plant wax signature, confirmed by the dominance of $n-C_{29}$, which indicates a mixed origin from forest and grassland. Furthermore, burning of shrubs, litter, trees, etc., produced similar CPI in the high end (Standley and Simoneit, 1987). On the contrary, the high end of the Spanish extract is characteristic of petroleum.

The source of these hydrocarbons from petroleum is confirmed by the suite of biomarkers found in such materials, as for example the triterpanes, and the hump or unresolved complex mixture in the TIC of the Irish and Spanish extracts. In fact, these samples exhibited a broad envelope of unresolved components ranging approximately from $n-\mathrm{C}_{16}$ to $n-\mathrm{C}_{38}$ for the 
Spanish and $n-\mathrm{C}_{18}$ to $n-\mathrm{C}_{32}$ for the Irish extract, which have been reported to be composed of highly branched and cyclic hydrocarbons, and ascribed to lubricating oil (Simoneit, 1985) and petroleum (Gough and Rowland, 1990).

According to Simoneit (1986) petroleum contains only minor amounts of long-chain fatty acids, and the homologs $<n-C_{20}$ and probably in part $<n-C_{24}$ are derived from microbial sources and the homologs $>n-\mathrm{C}_{22}$ from vascular plant wax. Later, Mazurek et al. (1991) split the homologous series of fatty acids into (1) low molecular weight acids $\left(\mathrm{C}_{6}-\mathrm{C}_{11}\right)$ from nonspecific degradation processes (e.g. microbial metabolism, combustion, thermal alteration, photochemical reaction); (2) intermediate molecular weight acids $\left(C_{12}-C_{19}\right)$ from recent biogenic sources (e.g. microorganisms, plant waxes; $\mathrm{CPI}>2$ ) or from combustion sources (e.g. vehicular emissions; CPI <2); and (3) high molecular weight acids $\left(\mathrm{C}_{20}-\mathrm{C}_{33}\right)$ derived from epicuticular waxes of vascular plant foliage. CPI for fatty acids from the Irish extract is 2.9 , and when broken down into molecular weight categories, the CPI for the $\mathrm{C}_{6}-\mathrm{C}_{11}$ range could not be calculated because this range can hardly be distinguished from background in the TIC trace, the CPI for the $\mathrm{C}_{12}-\mathrm{C}_{19}$ range is 3.4, and the CPI for the $C_{20}-C_{33}$ range is 2.4 . For the Belgian extract the CPI in the whole range is 5.1 (5.8 and 4.6, respectively) and for the Spanish extract is 1.9 (1.6 and 2.1, respectively). From all the three extracts, only the CPI for fatty acids in the Spanish sample agree with those of vehicular emissions, whereas it appears that the fatty acid fractions could have a biogenic origin in the Irish and Belgian extracts.

Diterpenoids are regarded as characteristic molecular markers for conifer resins (i.e.methyl dehydroabietate), and retene is an incomplete combustion product of compounds with the abietane skeleton (Standley and Simoneit, 1987). These compounds are frequent in cities in which residential wood combustion is widely used, and therefore could be observed in Dublin and Mechelen.

Polycyclic aromatic hydrocarbons are the result of combustion-generated airborne particulate matter, and have been identified, among other sources, in smoke particles from plant burning (Standley and Simoneit, 1987) and diesel engine soot (Yu and Hites, 1981). It is well known that organic compounds adsorbed onto the particulate phase of diesel exhaust posses direct-acting mutagenicity and can be accounted for by polycyclic aromatic hydrocarbons (Bayona et al., 1988). Polycyclic aromatic hydrocarbon mixtures encountered in crust extracts are complex because of the presence of alkyl-substituted compounds, as well as the numerous isomeric parent compounds. Generally, compounds from two to six aromatic rings are widely distributed in the three crust extracts, particularly in the Irish one. In addition, ketones, sulphur and nitrogen-substituted compounds were identified.
Petroleum biomarkers are compounds utilized for defining both the fossil origin and the geological source of the petroleum residues (Simoneit et al., 1988). An example is the $17 \alpha(\mathrm{H}), 21 \beta(\mathrm{H})$-hopane series, from which a few homologs eluted with some of the major peaks in the extracts. The hopanes are relatively easy to detect by using GC/MS and ion monitoring since two major fragment ions, $m / z 191$ and $m / z 148$ $+R$, are formed from the parent ion in the ion source of the mass spectrometer (Philp, 1985). These compounds, which are present in all the three extracts studied, are widely distributed in urban aerosols, originating from lubricating oil in vehicular emissions. An example of the distribution of the hopanes in the Irish and Belgian crust extracts is shown in Fig. 3 and the identity of the compounds is referred to in Table 1. Interestingly, the pattern is similar to those reported for crude oil (Philp, 1985), automobile and diesel engine exhausts (Simoneit, 1985), and for the Spanish crust (Fig. 2). Furthermore, triterpane patterns in both pyrolysates and extracts were identical, indicating that no differences were obtained irrespective of the analytical approach used.

From the data, it was concluded that the black crust contained molecular markers that are characteristic of petroleum derivatives. In addition, the identification of diterpenoids in the crusts pointed to the presence of smoke particles from wood combustion. Although similar classes of compounds were encountered in the black crust from the cathedral of Seville, only a trace of diterpenoids was identified, which is a consequence of the lack of residential wood burning in the city (SaizJimenez and Bernier, 1981; Saiz-Jimenez and Garcia del Cura, 1991). The overprint of some biogenic components of aerosols over petroleum components from anthropogenic emissions (mainly vehicular) can be illustrated by the dominance of hydrocarbons around $n-C_{29}$ (plant waxes) and fatty acids in the range $n-C_{12}-C_{19}$ (microorganisms and plant waxes). Accordingly, the black crusts coating the surfaces of building materials located in urban (polluted) environments contain all kind of organic compounds present in aerosols and particulate matter, which are transferred by dry and/or wet deposition. The composition of each crust is governed by the composition of the particular airborne pollutants in the area, and, even in the same city, composition can be different depending on the proximity of specific input sources. Finally, it appears clear that exposed building materials act as a non-selective surface, passively entrapping all deposited airborne particulate matter and organic compounds.

\section{Biological implications of airborne organic pollutant deposition}

Most bacteria and fungi are heterotrophic organisms that consume, not produce, organic matter. However, a small group of photosynthetic and chemoautotrophic bacteria fix carbon dioxide and are therefore classified as autotrophs. These organisms, of 

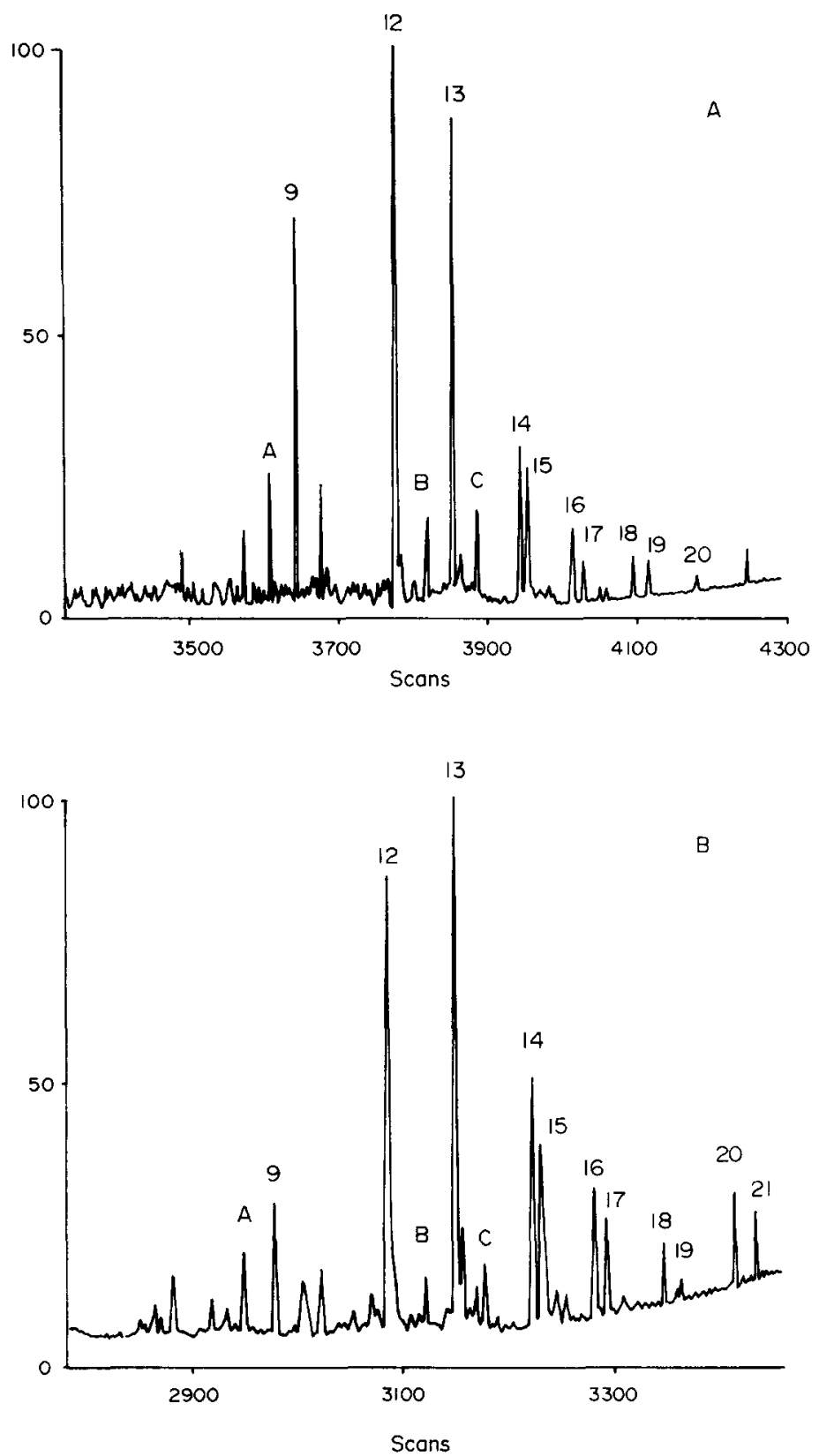

Fig. 3. (A) Mass fragmentogram ( $m / z 191)$ of the extract of black crust, Custom House, Dublin. (B) Mass fragmentogram $(\mathrm{m} / z$ 191) of the extract of black crust, cathedral of Mechelen. Peak numbers refer to Table 1. Peak letters refer to compounds absent in Table 1. A:18 $\alpha(\mathbf{H})-22,29,30$ trisnorhopane, $\quad$ B:17 $\beta(\mathrm{H}), 21 \alpha(\mathrm{H})-30$-normoretane, $\quad \mathrm{C}: 17 \beta(\mathrm{H}), 21 \alpha(\mathrm{H})$ moretane.

which sulphur and nitrifying bacteria are representatives, are rare in nature, and their share in the total production of organic matter is small. In contrast, most of the microorganisms living in rocks and stonework are heterotrophic bacteria and fungi. Both types appear to be involved in the weathering and formation of minerals and rocks.

Colonization and biodeterioration on stonework are usually linked to environmental conditions. The most significant parameters affecting microbial growth are represented by physical factors, mainly moisture, temperature and light, as well as by the chemical nature of the substrate. Lewis et al. (1988) suggested that bacteria on stone can be extremely versatile and could maintain their activity during nutrient perturbations, operating at low nutrient levels and utilizing what the environment has to offer. As a consequence, bacterial populations may be able to 
maintain their involvement in the process of stone deterioration during periods of nutrient flux.

A primary colonization of chemoautotrophic bacteria favours a settling in of heterotrophic bacteria and fungal populations. The activity of heterotrophic bacteria on stone is governed by the availability of suitable organic matter. It is likely that most stonework contains sufficient organic material from soil and dust or dead autotrophic and phototrophic organisms to maintain growth and activity of a large population of bacteria. Most heterotrophic bacteria are able to use various organic compounds as a source of carbon and energy for growth.

Warscheid et al. (1988) determined chemoorganotrophic bacteria from the uppermost layers of sandstone from German monuments. It was shown that most of the isolated bacteria used a wide range of different carbohydrates, amino acids, fatty acids and hydrocarbons. About $40 \%$ of the strains analysed were shown to be potential acid producers, whereas kerosene, as a representative mixture of different hydrocarbons detectable in polluted atmosphere, was well metabolized by $70 \%$ of the analysed bacteria.

It has been shown that in addition to bacteria, fungi can break down minerals mechanically or chemically. The fungi isolated from weathered stones are usually ubiquitous saprophytes whose conidia are readily distributed through the atmosphere. Most of the isolated species are commonly included in floristic listings. Aspergillus, Penicillium and Cladosporium are among the most common airborne fungi and thus have a worldwide distribution. Also, the fungi have a remarkable saprophytic and polysaccharide-degrading potential.

The presence of an organism on decayed material does not necessarily imply that it has caused the damage observed. The activity of microorganisms in promoting stone deterioration is largely dependent upon the production of corrosive metabolites which can solubilize minerals in a manner similar to chemical agencies.

Green algae flourish in walls as a response to rising damp from the ground, which originate a richer nutrient environment through dissolved salts and organic matter input. Many bacteria and fungi derive much of their carbon from organic substrates of which algal products may represent an appreciable proportion (e.g. mucilages and algal cell wall polysaccharides) and can give rise to organic acids.

However, in addition to saprophytic microorganisms, a more cryptic, autochtonous microflora, usually not evidenced in sugar-rich isolation cultures, is also functioning in the black crust ecosystem, as the isolation and study of a specific fungal flora revealed.

In fact, because cultures rich in organic carbon can mask the real fungal distribution in weathered stones and selectively isolate airborne propagules instead of functional structures, an approach involving direct isolation, through micromanipulation techniques, of fungi growing on incubated wet crusts was carried out. A very different fungal population to those previously reported (Petersen et al., 1988; De la Torre et al., 1991) was obtained. From the Seville cathedral, in addition to a few bacteria and actinomycetes not investigated, a dark chlamydospore-producing fungus was the only isolate, with a high presence in the tested crust samples $(82 \%)$. The isolate was not sporulating after several attempts to subculture on a variety of media and it was, therefore, impossible to provide an identification. However, one of the isolates showed a few poorly developed conidia characteristic of the genus Alternaria. This genus is known to produce chlamydospores especially in adverse environmental conditions. From Mechelen cathedral the species represented in a higher number of crust samples was Engyodontium album $(15 \%)$. Botriotrichum piluliferum, Ulocladium atrum and Mucor circinelloides were isolated in $4 \%$ of the samples. These fungi most probably use the organic compounds present in the black crusts, which include, among others, aliphatic hydrocarbons, fatty acids and tricyclic terpenoids, because no organic carbon was added for growth. Therefore it appears that two different types of fungal populations can be isolated from stones, those utilizing readily available carbon sources (carbohydrates) which are difficult to distinguish from ubiquitous saprophytic airborne fungi, and those using hydrocarbon derivatives originated from pollution sources.

Control of black crusts and organic compounds in building materials

Deposition of aerosols and particulate matter on building surfaces is a continuous process along the time. Obviously, control of deposition and black crust formation should be carried out by controlling environmental pollution rather than by periodic cleaning of façades. However, although it is recognized than traffic restrictions are frequent in some European historic areas, these types of actions are more psychological or political than useful and, generally, transport of pollutants from neighbouring areas subjected to traffic collects on historic building surfaces.

Black crusts due to wetting and drying processes, crystallization of salts and discontinuities between the gypsum and calcite layers are sometimes loosed and detached from surfaces. In other cases, the crusts are firmly coated on the stone. Removal of black sulphated crusts is considered a need based on aesthetic reasons and to ensure better preservation of materials. Cleaning methods have been reviewed by Amoroso and Fassina (1983) and Lazzarini and Tabasso (1986). They are divided into mechanical and chemical, the former including water sprinkling, water spray, steam, wet or dry grit blasting and microblasting. Chemical methods encompass the use of surfactants, emulsifying agents, acids, alkalis, organic solvents and absorbent clays. In addition, sophisticated methods such as laser and ultrasonic cleaning are employed. Generally, most of the cleaning methods not only remove the black crusts but also deeper stone layers, provoking further deterioration. Furthermore, if polished surfaces are not protected they are exposed to further attack. 
According to our experience, cleaning methods are applied to historic buildings, in many cases, without previous investigations into stone characteristics and origin and nature of the weathering layer. Different cleaning procedures are offered by specialized companies to owners, architects and decision-makers. Cleaning is thus routine work, and very often decided without the aid of scientific criteria and taking into consideration only aesthetic or circumstantial reasons (proximity of events). In Spain there are historic buildings which have been cleaned twice in the last 5 years. However, in spite of succesive cleaning, the stones continue weathering due to rain, wind, rising damp and air pollution. Downtown traffic, parking of cars just in front of the main façades of historic buildings, and abundance of bus stops around the most outstanding monuments guarantee the continuous blackening of the walls. Because no reduction of traffic or environmental pollution control in the cities (passive conservation) are adopted, periodic cleaning and removal of black crusts strongly contributes to a progressive thinness and to a severe deterioration of the stone surface.

Acknowledgement--This research has been supported by the CEC through contracts EV4V $0061 \mathrm{E}$ and STEP CT90-0107.

\section{REFERENCES}

Amoroso G. G. and Fassina V. (1983) Stone Decay and Conservation. Elsevier, Amsterdam.

Bayona J. M., Markides K. E. and Lee M. L. (1988) Characterization of polar polycyclic aromatic compounds in a heavy-duty diesel exhaust particulate by capillary column gas chromatography and high-resolution mass spectrometry. Envir. Sci. Technol. 22, 1440-1447.

Boyer K. W. and Laitinen H. A. (1975) Automobile exhaust particulates. Properties of environment significance. Envir. Sci. Technol. 9, 457-469.

Cristwell C. D., Ogawa I., Tschetter M. J. and Markuszewski R. (1988) Effect of hydrofluoric or hydrochloric acid pretreatment on the ultrasonic extraction of organic materials from fly ash for chromatographic analysis. Envir. Sci. Technol. 22, 1506-1508.

De la Torre M. A., Gomez-Alarcon G., Melgarejo P. and Saiz-Jimenez C. (1991) Fungi in weathered sandstone from Salamanca cathedral. Sci. Total Envir. 107, 159-168.

Del Monte M., Sabbioni C. and Vittori O. (1981) Airborne carbon particles and marble deterioration. Atmospheric Environment 15, 645-652.

Del Monte M., Sabbioni C. and Vittori O. (1984) Urban stone sulphation and oil-fired carbonaceous particles. Sci. Total Envir. 36, 369-376.

Department of Environment (1989) The effects of acid deposition on buildings and building materials in the United Kingdom. Building Effect Review Group Report, HMSO, London.

Gauri K. L. (1978) The preservation of stone. Scient. Am. 238, $104-110$.

Gillberg G., Gezelius L. H., Lööf G., Ringblom H. and Rosenquist K. (1977) Cleaning of external surfaces of buildings. In Proc.RILEM/ASTM/CIB Symp. Evaluation of the Performance of External Vertical Surfaces of Building, Espoo, Finland, pp. 144-153.

Gough M. A. and Rowland S. J. (1990) Characterization of unresolved complex mixtures of hydrocarbons in petroleum. Nature 344, 648-650.
Hoke E. (1978) Investigations of weathering crusts on Salzburg stone monuments. Stud. Conserv. 23, 118-126.

Lazzarini L. and Tabasso M. L. (1986) II Restauro della Pietra. CEDAM, Padova.

Lewis F. J., May E. and Bravery A. F. (1988) Metabolic activities of bacteria isolated from building stone and their relationship to stone decay. In Biadeterioration (edited by Houghton D. R., Smith R. N. and Eggins H. O. W.), Vol.7, pp. 107-112. Elsevier, London.

Leysen L., Roekens E., Komy Z. and van Grieken R. (1991) A study of the weathering of an historic building. Analytica Chim. Acta 195 247-255.

Mazurek M. A., Cass G. R. and Simoneit B. R. T. (1991) Biological input to visibility-reducing aerosol particles in the remote arid Southwestern United States. Envir. Sci. Technol. 25, 684-694.

Petersen K., Kuroczkin J., Strzelzyck A. B. and Krumbein W. E. (1988) Distribution and effects of fungi on and in sandstones. In Biodeterioration (edited by Houghton D. R., Smith R. N. and Eggins H. O. W.), Vol.7, pp. 455-460. Elsevier, London.

Philp R. P. (1985) Biological markers in fossil fuel production. Mass Spectr. Rev. 4, 1-54.

Saiz-Jimenez C. (1991) Characterization of organic compounds in weathered stones. In Science, Technology and European Cultural Heritage (edited by Baer N. S., Sabbioni C. and Sors A. I.), pp. 523-526. CEC, Butterworth-Heinemann, Oxford.

Saiz-Jimenez C. and Bernier F. (1981) Gypsum crusts on building stones. A scanning electron microscopy study. Paper 81/10/5. ICOM Committee for Conservation, 6th Triennial Meeting, Ottawa.

Saiz-Jimenez C. and Garcia del Cura M. A. (1991) Sulfated crusts: a microscopic, inorganic and organic analysis. In Science, Technology and European Cultural Heritage (edited by Baer N. S., Sabbioni C. and Sors A. I.), pp. 527530 CEC, Butterworth-Heinemann, Oxford.

Saiz-Jimenez C., Hermosin B., Ortega-Calvo J. J. and Gomez-Alarcon G. (1991) Applications of analytical pyrolysis to the study of stony cultural properties. J. analyt. appl. Pyrol. 20, 239-251.

Simoneit B. R. T. (1985) Application of molecular marker analysis to vehicular exhaust for source reconciliations. Int. J. envir. analyt. Chem. 22, 203-233.

Simoneit B. R. T. (1986) Characterization of organic constituents in aerosols in relation to their origin and transport: a review. Int. J. envir. analyt. Chem. 23, 207-237.

Simoneit B. R. T., Cox R. E. and Standley L. J. (1988) Organic matter of the troposphere-IV. Lipids in Harmattan aerosols of Nigeria. Atmospheric Environment 22, 983-1004.

Schroeder W. H. and Lane D. A. (1988) The fate of toxic airborne pollutants. Envir. Sci. Technol. 22, 240-246.

Standley L. J. and Simoneit B. R. T. (1987) Characterization of extractable plant wax, resin, and thermally matured components in smoke particles from prescribed burns. Envir. Sci.Technol. 21, 163-169.

Van der Kaaden A., Haverkamp J., Boon J. J. and de Leeuw J. W. (1983) Analytical pyrolysis of carbohydrates. I. Chemical interpretation of matrix influences on pyrolysismass spectra of amylose using pyrolysis-gas chromatography-mass spectrometry. J. analyt. appl. Pyrol. 5, 199-220.

Venema A. and Veurink J. (1985) A method for solvent free application of polymers and inorganic materials to ferromagnetic wires used for pyrolysis-capillary gas chromatography methods. J. analyt. appl. Pyrol. 7, 207-213.

Warscheid T., Oelting M. and Krumbein W. E. (1988) Physico-chemical aspects of biodeterioration processes on rocks with special regard to organic pollutants. Int. Biodet. 28, 37-48.

Yu M.-L. and Hites R. A. (1981) Identification of organic compounds on diesel engine soot. Analyt. Chem. 53, 951-954. 